\title{
Relationship between Cigarette Smoking and Candida Colony Count in Dental Student at Faculty of Dentistry University of Sumatera Utara
}

\author{
Puteri Ridha Ramadhani, Nurdiana, Pocut Astari \\ Department of Oral Medicine \\ Faculty of Dentistry, University of Sumatera Utara \\ Medan, Indonesia
}

\begin{abstract}
Cigarette smoking can be described as an activity where a person is enjoying the nicotine smoke produced from the burning tobacco. It contains 4800 chemical substances that are harmful to the body such as nicotine, tar, and carbon monoxide, which then cause changes to the oral cavity. One of the changes is the increase of candida colony count that will lead to abnormal alterations of the oral cavity such as candidiasis. The aim of this study was to find the relationship between cigarette smoking and candida colony count in dental student at Faculty of Dentistry, University of Sumatera Utara using analytic method with cross sectional approach. The study was conducted at Faculty of Dentistry University of Sumatera Utara and Microbiology Laboratory Faculty of Maths and Sciences University of Sumatera Utara on 57 male active smokers. Questionnaire was given to the subjects to gain information about smoking habits and swabs from dorsal of the tongue were examined. The data was statistically analysed using chisquare and $p$ value $<0,05$ considered as statistically significant. The results showed that subjects were mostly found to be in age group range 17-25 years old. Duration of smoking mostly found was $\geq 6$ years. Number of cigarettes mostly smoked was $>10$ cigarettes per day. The type of cigarette mostly smoked was filtered-cigarette. Cigarette exposure time mostly found was $>15$ cigaretteyears. There was a significant relationship between candida colony count and number of cigarettes smoked $(p=0,029)$, but not with duration of smoking $(p=0,326)$. There was also significant relationship between candida colony count and cigarette exposure time $(p=0,001)$, but not with the type of cigarette consumed $(p=0,951)$. The conclusions are both number of cigarettes smoked and cigarette exposure time have significant relationships with candida colony count whereas duration of smoking and type of cigarette did not have significant relationships with candida colony count.
\end{abstract}

Keywords-candida colony count, cigarette smoking, duration of smoking, number of cigarettes smoked, type of cigarette, cigarette exposure time

\section{INTRODUCTION}

Cigarette smoking is an activity where a person is enjoying the nicotine smoke produced from the burning tobacco [1]. It is one of the biggest issues causing many health problems towards 6 million people and directly responsible for 5 million deaths every year [2]. Riset Kesehatan Dasar (RISKESDAS) reported in 2010 that $34.7 \%$ Indonesians aged above 10 years old are smokers [3]. Cigarette smoking had caused many deaths of more than 200 thousands Indonesians every year [4].

Cigarette smoke contains 4800 different types of chemical substances that are harmful to the body [1]. Those substances such as tar, nicotine, carbon monoxide, and nitric oxide will enter the body cells and overtime it can cause damage to the organs especially heart and lungs [1,5,6]. Cigarette smoking is a risk factor to oral diseases such as oral cancer, periodontal diseases, and congenital defect [7]. Oral mucosal can also be affected because cigarettes contain many substances that are toxic, and carsinogenic [6].

Cigarette smoking is a cause to many abnormal alterations that can begin with an increase of candida colony count that causes oral diseases such as pseudo membrane candidiasis, acute atopic candidiasis, chronic hyperplastic candidiasis, chronic atopic candidiasis, and angular cheilitis [8]. Other factors such as long-term antibiotic consumption, HIV infection, diabetes mellitus, radiotherapy, bad oral hygiene, dental prostheses, and cigarette smoking can also contributes to an increase of candida colony count $[8,9,10]$.

The studies conducted by Muzurovic et al. in 2013 showed that candida are mostly found in smokers $(82.5 \%)$. Cigarette smoking has many bad impacts towards oral heatlh [8]. However, Darwazeh et al.. in 2010 found that smoking did not cause an increase to oral candida colony count on healthy smokers who has neither systemic disease nor antibiotic consumption [11].

The aim of this study is to find the relationship between candida colony count and duration of smoking, number of cigarettes, types of cigarettes, and cigarette exposure time. 


\section{MATERIALS AND METHODS}

This study was conducted using analytic method with cross sectional approach. Population of this study were student of Faculty of Dentistry University of Sumatera Utara who smoked. Sampling technique used was purposive sampling. This study was done on 57 male smoker that were qualified based on the inclusion criteria. Those criteria were male smoker who actively smoked during the past year, did not have any systemic disease or consuming antibiotic, and willing to be a subject. Subjects who vomited during the process of obtaining the sample from the dorsal of the tongue and were not cooperative, were excluded.

Data were collected from male dental student who smoked by firstly explaining the aim of this study. After they agreed to be a subject, an informed consent was given. Questionnaire were then filled in by the researcher asking the subject about smoking habits which includes duration of smoking, number of cigarette smoked, types of cigarette, and cigarette exposure time. The data was statistically analysed using chi-square and $\mathrm{p}$ value $<0,05$ considered as statistically significant.

\section{RESULTS}

Subjects from age group 17-25 years old were more represented, $50(87.7 \%)$ than those aged 26-36 years old, $7(12.3 \%)$ as shown in Table I.

TABLE I. DISTRIBUTION AND FREQUENCY OF SUBJECTS AGE

\begin{tabular}{|c|c|c|} 
AGE \\
\begin{tabular}{|c|c|c|}
\hline Age (Year) & Frequency (n) & Percentage (\%) \\
\hline $17-25$ & 50 & 87,7 \\
\hline $26-36$ & 7 & 12,3 \\
\hline Total & 57 & 100 \\
\hline
\end{tabular}
\end{tabular}

Candida colony count $\leq 100 \mathrm{cfu} / \mathrm{ml}$ were identified lesser, 15 (26.3\%) compared to those who have $>100$ cfu/ml, 42 (73.7\%) (Table II).

TABLE II. DISTRIBUTION AND FREQUENCY OF SUBJECTS BASED ON CANDIDA COLONY COUNT

\begin{tabular}{|c|c|c|}
\hline $\begin{array}{c}\text { Candida colony } \\
\text { count (cfu/ml) }\end{array}$ & Frequency (n) & Percentage (\%) \\
\hline$\leq 100$ & 15 & 26,3 \\
\hline$>100$ & 42 & 73,7 \\
\hline Total & 57 & 100 \\
\hline
\end{tabular}

Duration of smoking is divided into two categories, $1-5$ years and $\geq 6$ years. This study showed that 28 $(49.1 \%)$ subjects had been smoking for $1-5$ years, whereas $29(50.9 \%)$ subjects smoked for $\geq 6$ years (Table III). In 28 subjects who smoked for $1-5$ years, 9 (32.1\%) had candida colony count $\leq 100 \mathrm{cfu} / \mathrm{ml}$ and 19 $(67.9 \%)$ subjects had $>100 \mathrm{cfu} / \mathrm{ml}$. However, among those who smoked $\geq 6$ years, $6(20.7 \%)$ had $\leq 100 \mathrm{cfu} / \mathrm{ml}$ and the other $23(79.3 \%)$ had $>100 \mathrm{cfu} / \mathrm{ml}$. There was no significant relationship between duration of smoking and candida colony count ( $p>0.05$ ) (Table IV).
TABLE III. DISTRIBUTION AND FREQUENCY OF SUBJECTS BASED DURATION OF SMOKING

\begin{tabular}{|c|c|c|}
\hline $\begin{array}{c}\text { Duration of smoking } \\
\text { (years) }\end{array}$ & Frequency (n) & Percentage (\%) \\
\hline $1-5$ & 28 & 49,1 \\
\hline$\geq 6$ & 29 & 50,9 \\
\hline Total & 57 & 100 \\
\hline
\end{tabular}

TABLE IV. RELATIONSHIP BETWEEN DURATION OF SMOKING AND CANDIDA COLONY COUNT

\begin{tabular}{|c|c|c|c|c|c|}
\hline \multirow{3}{*}{$\begin{array}{c}\text { Duration of } \\
\text { smoking } \\
\text { (years) }\end{array}$} & \multicolumn{4}{|c|}{ Candida colony count (cfu/ml) } & \multirow{3}{*}{$\mathbf{P}$} \\
\hline & \multicolumn{2}{|c|}{$\leq 100$} & \multicolumn{2}{|c|}{$>100$} & \\
\hline & $\mathrm{N}$ & $\%$ & $\mathrm{~N}$ & $\%$ & \\
\hline $1-5$ & 9 & 32,1 & 19 & 67,9 & \multirow{3}{*}{0,326} \\
\hline$\geq 6$ & 6 & 20,7 & 23 & 79,3 & \\
\hline Total & 15 & 26,3 & 42 & 73,3 & \\
\hline
\end{tabular}

This study showed that in 28 (49.1\%) subjects who smoked 1-10 cigarettes per day (Table 5), 11 (39.3\%) had candida colony count $\leq 100 \mathrm{cfu} / \mathrm{ml}$ and $17(60.7 \%)$ had $>100 \mathrm{cfu} / \mathrm{ml}$ (Table 6). Among 29 (50.9\%) subjects who smoked $>10$ cigarettes per day (Table V), 4 $(13.8 \%) \mathrm{had} \leq 100 \mathrm{cfu} / \mathrm{ml}$ and $25(86.2 \%)$ had $>100$ $\mathrm{cfu} / \mathrm{ml}$. This shows that there was a significant relationship between number of cigarettes and candida colony count $(\mathrm{p}<0.05)$ (Table VI).

TABLE V. DISTRIBUTION AND FREQUENCY OF SUBJECTS BASED ON NUMBER OF CIGARETTES

\begin{tabular}{|c|c|c|}
\hline $\begin{array}{c}\text { Number of } \\
\text { cigarettes }\end{array}$ & Frequency (n) & Percentage (\%) \\
\hline $1-10$ & 28 & 49,1 \\
\hline$>10$ & 29 & 50,9 \\
\hline Total & 57 & 100 \\
\hline
\end{tabular}

TABLE VI. RELATIONSHIP BETWEEN NUMBER OF CIGARETTES AND CANDIDA COLONY COUNT

\begin{tabular}{|c|c|c|c|c|c|}
\hline \multirow{2}{*}{$\begin{array}{c}\text { Number of } \\
\text { cigarettes }\end{array}$} & \multicolumn{2}{|c|}{ Candida colony count (cfu/ml) } & \multirow{2}{*}{ P } \\
\cline { 2 - 5 } & $\mathbf{2}$ & $\mathbf{S 1 0 0}$ & \multicolumn{2}{|c|}{$>\mathbf{1 0 0}$} & \\
\hline $1-10$ & 11 & 39,3 & 17 & $\%$ & \\
\hline$>10$ & 4 & 13,8 & 25 & 86,7 & \multirow{2}{*}{0,029} \\
\hline Total & 15 & 26,3 & 42 & 73,7 & \\
\hline
\end{tabular}

This study found that filtered cigarettes were more chosen by the subjects 53 (93\%) compared to Kreteks 4 (7\%) (Table VII). Those 4 subjects who smoked Kreteks, $1(25 \%)$ had $\leq 100 \mathrm{cfu} / \mathrm{ml}$ and $3(75 \%)$ had $>100 \mathrm{cfu} / \mathrm{ml}$. in 53 subjects who smoked filtered cigarettes, $14(26.4 \%)$ had $\leq 100 \mathrm{cfu} / \mathrm{ml}$ and $39(73.6 \%)$ had $>100 \mathrm{cfu} / \mathrm{ml}$. However, there is no significant relationship between type of cigarette and candida colony count ( $p>0.05)$ (Table VIII).

TABLE VII. DISTRIBUTION AND FREQUENCY OF SUBJECTS BASED ON TYPE OF CIGARETTE

\begin{tabular}{|c|c|c|}
\hline Type of cigarettes & Frequency (n) & Percentage (\%) \\
\hline Kreteks & 4 & 7 \\
\hline Filtered & 53 & 93 \\
\hline Total & 57 & 100 \\
\hline
\end{tabular}


TABLE VIII. RELATIONSHIP BETWEEN TYPE OF GIGARETTE AND CANDIDA COLONY COUNT

\begin{tabular}{|c|c|c|c|c|c|}
\hline \multirow{2}{*}{$\begin{array}{c}\text { Type of } \\
\text { cigarette }\end{array}$} & \multicolumn{3}{|c|}{ Candida colony count $(\mathbf{c f u} / \mathbf{m l})$} & \multirow{2}{*}{ P } \\
\cline { 2 - 5 } & \multicolumn{2}{|c|}{$\leq \mathbf{1 0 0}$} & \multicolumn{2}{c|}{$>\mathbf{1 0 0}$} & \\
\cline { 2 - 5 } & $\mathrm{N}$ & $\%$ & $\mathrm{~N}$ & $\%$ & \\
\hline Kreteks & 1 & 25,0 & 3 & 75,0 & \multirow{2}{*}{0,951} \\
\hline Filtered & 14 & 26,4 & 39 & 73,6 & \\
\hline Total & 15 & 26,3 & 42 & 73,7 & \\
\hline
\end{tabular}

Group of subjects with cigarette exposure time $\leq 15$ cigarette-years were found lesser, $10(17.5 \%)$ compared to those with $>15$ cigarettes years $47(82.5 \%$ ) (Table IX). In 10 subjects with $\leq 15$ cigarette years, 7 (70\%) had $\leq 100 \mathrm{cfu} / \mathrm{ml}$ and $3(30 \%)$ had $>100 \mathrm{cfu} / \mathrm{ml}$ whereas those with $>15$ cigarette years, $8(17 \%)$ had $\leq 100$ $\mathrm{cfu} / \mathrm{ml}$ and $39(83 \%)$ had $>100 \mathrm{cfu} / \mathrm{ml}$. This shows that there is a significant relationship between cigarette exposure time and candida colony count $(\mathrm{p}<0.05)$ (Table X).

TABLE IX. DISTRIBUTION AND FREQUENCY OF SUBJECTS BASED ON CIGARETTE EXPOSURE TIME CIGARETTE EXPOSURE TIME

\begin{tabular}{|c|c|c|}
\hline $\begin{array}{c}\text { Cigarette exposure time } \\
\text { (cigarette-years) }\end{array}$ & $\begin{array}{c}\text { Frequency } \\
(\mathbf{n})\end{array}$ & Percentage (\%) \\
\hline$\leq 15$ & 10 & 17,5 \\
\hline$>15$ & 47 & 82,5 \\
\hline Total & 57 & 100 \\
\hline
\end{tabular}

TABLE X. RELATIONSHIP BETWEEN CIGARETTE EXPOSURE TIME AND CANDIDA COLONY COUNT

\begin{tabular}{|c|c|c|c|c|c|}
\hline \multirow{2}{*}{$\begin{array}{c}\text { Cigarette } \\
\text { exposure time } \\
\text { (cigarette-years) }\end{array}$} & \multicolumn{4}{|c|}{$\begin{array}{c}\text { Candida colony count } \\
\text { (cfu/ml) }\end{array}$} & \multirow{2}{*}{ P } \\
\cline { 2 - 5 } & \multicolumn{2}{|c|}{$\leq \mathbf{1 0 0}$} & \multicolumn{2}{|c|}{$>\mathbf{1 0 0}$} & \\
\cline { 2 - 5 } & $\mathrm{N}$ & $\%$ & $\mathrm{~N}$ & $\%$ & \\
\hline$\leq 15$ & 7 & 70,0 & 3 & 30,0 & \multirow{2}{*}{0,001} \\
\hline$>15$ & 8 & 17,0 & 39 & 83,0 & \\
\hline Total & 15 & 26,3 & 42 & 73,7 & \\
\hline
\end{tabular}

\section{DISCUSSION}

Cigarette smoking is an activity where a person is enjoying the nicotine smoke produced from the burning tobacco and considered as a normal lifestyle [1,12]. Nicotine is an addictive chemical substances that causes addiction [5,12]. Cigarette smoking can be studied from different perspective such as duration of smoking, number of cigarettes, type of cigarette, and cigarette exposure time [13]. According to literature, cigarette smoking can alters the oral flora normal such as candida to proliferate above normal count which is $>100 \mathrm{cfu} / \mathrm{ml}$. These changes will have impacts on oral health and causes candidiasis $[6,8,10,14]$.

Candida colony count $>100 \mathrm{cfu} / \mathrm{ml}$ were identified in $42(73.7 \%)$ subjects than $\leq 100 \mathrm{cfu} / \mathrm{ml}$ in only 15 $(26.3 \%)$. Results of this study were in accordance with the results of the study conducted by Muzurovic et al, where candida were isolated more in smokers $(82.5 \%)$ $[8,14]$. Cigarette smoke contains toxic substances such as benzo[a]pyrene and polynuclear aromatic hydrocarbon which responsible for oral abnormal alterations (increase in epithelial thickness, increase in candida adhesion, decrease in saliva flow rate and $\mathrm{pH}$ $[6,10,15,16]$. These conditions promote candida growth and development causing an increase in candida colony count thus results in oral diseases [17].

The results of this study showed $29(50.9 \%)$ subjects have smoked for $\geq 6$ years. This were supported by RISKESDAS reported in 2010 that people started smoking at the mean age of 10 years old which can be the reason why duration of smoking $\geq 6$ years were mostly found as this study were done on dental student [3]. In this study among the subjects who have smoked for $\geq 6$ years, $23(79.3 \%)$ were found to have candida colony count $>100 \mathrm{cfu} / \mathrm{ml}(\mathrm{p}>0.05)$. Those data are in accordance with the results of studies conducted by Odeh et al, who proved that there was no statistically significant correlation between duration of smoking and candida colony count. Smoking were found to be in proportional to the age of the subjects therefore candida colony count usually increased with age [19].

Smokers are classified into two groups, light smoker (1-10 cigarettes per day) and heavy smoker (>10 cigarettes per day) $[11,13,14]$. There were $29(50.9 \%)$ subjects who smoked $>10$ cigarettes per day and these data are in accordance to the studies conducted by Keten et al who found that subjects consuming $>10$ cigarettes per day were mostly found with average 15.38 cigarettes per day [19]. People usually smoke after waking up, after having a meal, while driving, and even when they are unoccupied. Smokers find it hard to refrain from smoking because it contains nicotine that cause people to be addicted [5,7,12,19]. In 29 subjects who have smoked $>10$ cigarettes per day, $25(86.2 \%)$ were found to have $>100 \mathrm{cfu} / \mathrm{ml}(\mathrm{p}<0.05)$. Those data are in accordance to the studies conducted by Hosseini et al who proved statistically significant relationship between number of cigarettes and candida colony count [20]. Cigarette smoke produced contains toxic substances such as polycyclic aromatic hydrocarbon nitrosodietheinalamine, nitrosoprolin, and nicotine. Consuming a lot of cigarettes will continuously exposing oral cavity with those substances. These exposure can cause irreversible abnormal alterations to the cells that will effect proliferation and differentiation $[16,19,21]$. Stratified squamous epithelial is an outer layer of oral mucosa that gets keratinized by masticatory forces. Each layer of epithelial cells has different stage of maturation. The outer layer will constantly being shed and replaced from below [16]. This is the result of a balance between the physiological cell death (apoptosis) and proliferation cells. Nicotine in cigarettes prevent the mechanisms of apoptosis causes the absence of physiological cell death leading to the over production of epithelial cells [16,21]. Production of cells located in the basal layer will have high proliferative activity while the degeneration process of the outer layer cells were prevented. These alterations cause epithelial layers to thickened and candida increases its proliferation after being exposed to toxic substances produced from cigarettes [14,16,19,22].

Type of cigarette mostly consumed was a filtered cigarette, by 53 (93\%) subjects compared to Kreteks by only $4(7 \%)$. Those data were supported by theories 
that stated filtered cigarettes have a filter sponge at the end of the cylinder to decrease the smoke produced from the burning tobacco so that the effect can be minimalized [6,15]. Kreteks have been analysed to have produced higher nicotine, carbon monoxide, and tar than filtered cigarette $[15,23]$. This reason motivates smoker to choose filtered cigarettes over Kreteks. However, the results of this study showed no significant relationship between type of cigarette and candida colony count $(p>0.05)$. Roemer et al reported that cloves were found in Kreteks but nor in filtered cigarettes, which contain eugenol that can minimalize the toxic effects produced. This is why filtered cigarettes are not any safer than Kreteks [23].

Cigarette exposure time is also responsible for any health issues [5]. This study showed that cigarette exposure time $>15$ cigarette-years were mostly found, in $47(82.5 \%)$ subjects compared to $\leq 15$ cigarette-years, in $10(17.5 \%)$. Those data are in accordance to the studies conducted by Keten et al who found that smokers tend to have cigarette exposure time of $>15$ cigarette-years with average 20.41 cigarette-years [19]. Cigarette-years is a unit used to find cigarette exposure time of a smoker by calculating duration of smoking times number of cigarettes smoked. If a person have been smoking one cigarette per day for a year that means he has cigarette exposure time of 1 cigaretteyears [13]. In 47 subjects who have $>15$ cigarette-years, $39(83 \%)$ were found to have candida colony count $>100 \mathrm{cfu} / \mathrm{ml}$. There was a significant relationship between cigarette exposure time and candida colony count $(\mathrm{p}<0.05)$.

Cigarette smoking can cause many health problems both systemic and oral [5]. Oral health problems can be initiated by an increase of candida colony count $[8,10]$. This increase in number are caused by toxic exposure produced from cigarette giving opportunities for candida to proliferate above normal and causes oral changes such as candidiasis $[8,11]$.

Pathogenesis of candida will increase when the production and secretion of External Transcribed Spacer 1 (ETS1)-Associated protein 1 (EAP1) and secreted aspartyl proteases (Sap) increases, causing protein that responsible for host defence mechanisms to decrease $[9,24]$. EAP1 gene has an ability to increase candida adhesion towards epithelial cells while Sap gene contributes to the transition of candida from blastopore into hypha $[9,22,25]$. Hypha formation leads to infection started by the mechanism of hypha entering the epithelial layers and interrupts the process between cells. Hypha also capable of damaging the endothelial cells that results in lysis of macrophage and neutrophil that are responsible for destroying the pathogens [25]. Candida that is being exposed to cigarette smoke for too long can lead to an increase in production and secretion of EAP1 and Sap genes which contributes to the rise of oral candida colony count [9].

\section{REFERENCES}

[1] S. Tirtosastro, A.S. Mudiyati, "Kandungan kimia tembakau dan rokok," Buletin Tanaman Tembakau, Serat \& Minyak Industri, vol. 2(1), pp. 33-43, April 2010.

[2] WHO. (2016, September 9) Tobacco. Available: http://www.who.int/mediacentre/factsheets/fs339/en/.

[3] Riskesdas. (2016, October 17) Masalah merokok di Indonesia Available: http://www.promkes.depkes.go.id/dl/factsheet1cov. pdf.

[4] M. Eriksen, J. Mackay, N. Schluger, F.I Gomeshtapeh, J. Drope, The tobacco atlas, the American cancer society. $5^{\text {th }}$ ed., Atlanta: the American Cancer Society Inc., 2015, pp. 1-2.

[5] R.M. Benjamin. How tobacco smoke cause disease: what it means to you. A report of the surgeon general. Centers for Disease Control U.S. Department of Human Health and Services, pp. 2-16, 2010.

[6] V. Trandafir, D. Trandafir, D. Gogalniceanu, E. Popescu, C. Vicol, V. Burlui, "Tobacco-induced oral mucosal modifications," Int. J. of Med. Dent., vol. 1(1), pp. 84-91, 2011.

[7] P.E. Petersen, "Tobacco and oral health - the role of the World Health Organization,” Oral Health Prev. Dent., vol. 1, pp. 309315, 2003.

[8] S. Muzurović, M. Hukić, E. Babajić, R. Smajić, "The relationship between cigarette smoking and oral colonization with Candida species in healthy adult subjects," Med. Glas., vol. 10(2), pp. 397-399, 2013.

[9] A. Semlali, K. Killer, H. Alanazi, W. Chmielewski, M Rouabhia M, "Cigarette smoke condensate increases C. albicans adhesion, growth, biofilm formation, and EAP1, HWP1 and SAP2 gene expression," BMC Microbiology, vol. 14, pp. 1-9, 2014

[10] P.A. Krishnan PA, "Fungal infections of the oral mucosa," Indian Journal of Dent. Research, vol. 23(5), pp. 650-9, 2012.

[11] A.M. Darwazeh, Z. Al-Dwairi, A. Zwiri, "The relationship between tobacco smoking and oral colonization with candida species,' The Journal of Contemporary Dental Practice, vol. 11(3), pp. 1-7, 2010.

[12] Kementrian Kesehatan RI, "Aliansi bupati/walikota dalam pengendalian masalah kesehatan akibat tembakau dan penyakit tidak menular," Buletin Jendela Data dan Informasi Kesehatan, vol. 2, pp. 29-41, December 2012.

[13] A. Indrayan, R. Kumar, "A simple index of smoking," Cobra Preprint Series, vol. 1-20, 2008.

[14] T. Becker, D. Porat, M. Gorsky, "The association between smoking habit and candida in the oral cavity," Int. J. Dentist Oral Health, vol. 1(2), pp. 1-3, 2015.

[15] O. Geiss, D. Kotzias D, "Tobacco, cigarettes and cigarette smoke: An overview," Institute for Health and Consumer Protection, pp. 40-53, 2007.

[16] A. Michcik, et al., "Tobacco smoking alters the number of oral epithelial cells with apoptotic features," Folia Histochemica Et Cytobiologica, vol. 52(1), pp. 60-68, 2014.

[17] B.S. Raju, S. Rajappa, "Review article: isolation and identification of candida from the oral cavity," International Scholarly Research Network, pp. 1-7, 2011.

[18] N.D. Odeh, O. Abu-Hammad, A. Kutkut, M. Samara, Z. Badr, M. Hamdan, et al, "Oral candida carriage in waterpipe and cigarette smokers with various dietary habits," International Archieves of Medicine Section: Microbiology, vol. 9(153), pp. 1-7, 2016.

[19] H.S. Keten, D. Keten, H. Ucer, F. Yildirim,H. Hakkoymaz, O. Isik, "Prevalence of oral candida carriage and candida species among cigarette and maras powder users," Int. J. Clin. Exp. Med., vol. 8(6), pp. 9847-9854, 2015.

[20] S.K. Hosseini, A.R.R. Far, F. Amani, "Evaluation of presence of candida in complete denture wearer in tissue and denture surfaces using smear method," Journal of Research in Medical and Dental Science, vol. 4(1), pp. 42-48, 2014.

[21] J. Arredondo, V.T. Nguyen, A.I. Chernyavsky, D.L. Jolkovsky, K.E. Pinkerton, S.A. Grando, "A receptor-mediated mechanism of nicotine toxicity in oral keratinocytes," Laboratory Investigation, vol. 81(12), pp. 1653-1668, 2001.

[22] H. Alanazi, A. Semlali, L. Perraud, W. Chmielewski, A. Zakrzewski, M. Rouabhia, "Cigarette smoke-exposed candida albocans increased chitin production and modulated human 
fibroblast cell response," Bio. Med. Research International, pp. $1-8,2014$.

[23] E. Roemer, R. Dempsey, M.K. Schorp. Toxicological assessment of kretek cigarettes part 1: background, assessment approach, and summary of findings," Regulatory Toxicology and Pharmacology, vol. 70, pp. 2-14, 2014.
[24] L. Treagan, "Candida and its role in opportunistic mycoses," California Association for Medical Laboratory Technology, pp $1-15,2011$.

[25] D.S. Thompson, P.L. Carlisle, D. Kadosh, "Coevolution of morphology and virulence in candida species," Eukaryotic Cell, vol. 10(9), pp. 1173-1182, 2011. 